\title{
First records of the dwarf surf clam Mulinia lateralis (Say, 1822) in Europe
}

\author{
J. A. Craeymeersch ${ }^{1 *} \mathbb{D}$, M. A. Faasse ${ }^{2,3}$, H. Gheerardyn², K. Troost ${ }^{1}$, R. Nijland ${ }^{5} \mathbb{D}$, A. Engelberts ${ }^{4} \mathbb{D}$, K. J. Perdon ${ }^{1}$, \\ D. van den Ende ${ }^{1}$ and J. van Zwol ${ }^{1}$
}

\begin{abstract}
This paper reports the first records of the dwarf surf clam Mulinia lateralis (Say, 1822) outside its native area, which is the western Atlantic Ocean, ranging from the Gulf of St Lawrence to the Gulf of Mexico. In 2017 and 2018 specimens were found in the Dutch coastal waters (North Sea), in the Wadden Sea and in the Westerschelde estuary, in densities of up to almost 6000 individuals per square meter. In view of its ecology and distributional range in the native area $M$. lateralis has the potential to become an invasive species. Its ability to quickly colonize defaunated areas, its high fecundity and short generation time, its tolerance for anoxia and temperature extremes and its efficient exploitation of the high concentrations of phytoplankton and natural seston at the sediment-water interface may bring it into competition with native species for food and space.
\end{abstract}

Keywords: Mulinia lateralis, Bivalvia, Marine, North Sea, Invasive, Competition

\section{Introduction}

For at least half a century, the process and the environmental, economic and social impacts of invasions of non-indigenous species are a focus of ecological research (Elton 1958; Rilov and Crooks 2009; Marbuah et al. 2014). As early as 1969 ICES had established a working group to address multiple research and applied issues related to bio-invasions, such as early detection and alerts to potential spread, population dynamics and distribution, ecological impacts, and risk assessments (see WGITMO 2018 for the latest report). Nowadays, many governments set up management goals and regulations to prevent the introduction and spread of alien species (e.g. Canada 2014; EU 2014; Australia 2016).

Meanwhile, many non-indigenous species have been introduced in NW European coastal waters. Gollasch et al. (2008) report 167 species to have been introduced in the North Sea. The authors show that there are relatively many records from the Netherlands and attribute this to the most intensive

\footnotetext{
* Correspondence: johan.craeymeersch@wur.nl

${ }^{1}$ Wageningen Marine Research, Wageningen University, P.O. Box 77, 4400,

$A B$, Yerseke, the Netherlands

Full list of author information is available at the end of the article
}

shipping (Port of Rotterdam) and aquaculture (Oosterschelde estuary) activities in the North Sea region (see also Wolff 2005). The most successful taxa regarding introduction and immigration are polychaetes, bivalves and amphipods (Reise et al. 1999; Zettler et al. 2018).

The number of non-indigenous species is still increasing. In the Netherlands already two new species have been recorded in 2018 (Faasse 2018a, 2018b). Here we report the first records of a new non-indigenous bivalve species in the North Sea: Mulinia lateralis (Say, 1822). The vernacular name of $M$. lateralis in English is dwarf surf clam or coot clam. As a Dutch vernacular name for this species, we propose 'Amerikaanse strandschelp', given the Dutch name for other species of the Mactridae in Dutch waters (Mactra and Spisula), and the American origin.

\section{Detection and distribution}

Mulinia lateralis has now been found in coastal waters and estuaries in the Netherlands. The first specimens were found during surveys in the southwestern Dutch coastal zone (the Voordelta) in September 2017, and again in June 2018. In the period of March to June 2018 specimens were also found in the 
Table 1 Records of Mulinia lateralis in the Netherlands: year, month, geographical area, geographical positions (WGS84) and density (ind $/ \mathrm{m}^{2}$ ) (see Fig. 1)

\begin{tabular}{|c|c|c|c|c|c|c|}
\hline Year & Month & Area & Longitude & Latitude & Tidal zone & Density (n/m2) \\
\hline \multirow[t]{5}{*}{2017} & October & Voordelta & 3.79238 & 51.75976 & sublittoral & 1.1 \\
\hline & October & Voordelta & 3.81156 & 51.80296 & sublittoral & 1260.6 \\
\hline & October & Voordelta & 3.80793 & 51.80274 & sublittoral & 5872.4 \\
\hline & October & Voordelta & 3.79570 & 51.78147 & sublittoral & 3.3 \\
\hline & October & Voordelta & 3.63029 & 51.71996 & sublittoral & 0.1 \\
\hline \multirow[t]{16}{*}{2018} & May & Eems & 6.91667 & 53.35417 & intertidal & 4.9 \\
\hline & May & Eems & 6.91667 & 53.35833 & intertidal & 9.8 \\
\hline & May & Eems & 6.91667 & 53.36250 & intertidal & 9.8 \\
\hline & May & Eems & 6.91250 & 53.39375 & intertidal & 2.4 \\
\hline & May & Eems & 6.91667 & 53.39583 & intertidal & 2.4 \\
\hline & June & Voordelta & 3.80000 & 51.80000 & sublittoral & 1003.1 \\
\hline & June & Voordelta & 3.83333 & 51.77500 & sublittoral & 7.1 \\
\hline & June & Voordelta & 3.83333 & 51.79167 & sublittoral & 0.8 \\
\hline & June & Voordelta & 3.83333 & 51.80000 & sublittoral & 54.8 \\
\hline & May & Waddenzee & 5.85000 & 53.40000 & intertidal & 2.4 \\
\hline & May & Waddenzee & 5.67500 & 53.34167 & intertidal & 2.4 \\
\hline & May & Waddenzee & 5.66250 & 53.38125 & intertidal & 2.4 \\
\hline & May & Waddenzee & 5.28333 & 53.18333 & intertidal & 2.4 \\
\hline & March & Waddenzee & 5.10833 & 52.98750 & sublittoral & 0.8 \\
\hline & September & Westerschelde & 4.07012 & 51.36747 & intertidal & 820.0 \\
\hline & September & Westerschelde & 4.06945 & 51.36606 & intertidal & unknown \\
\hline
\end{tabular}

Wadden Sea and Ems estuary, and in September 2018 in the Westerschelde estuary (Table 1 and Fig. 1).

\section{Morphological identification}

The family Mactridae is characterized by two cardinal teeth in the left valve fused in the shape of a ' $\Lambda$ ' (Signorelli and Pastorino 2012a). Our specimens agree with the diagnosis of the subfamily Mactrinae by Signorelli and Carter (2016). In several genera within this subfamily the external ligament has been reduced to a varying degree. According to Gardner (1928) the genus Mulinia Gray, 1837 represents the final stage in the reduction of the external ligament to a remnant below the hinge line. We compared the diagnoses of the 25 recent genera within the subfamily Mactrinae (MolluscaBase 2018a) from a number of literature sources with our collected specimens, and conclude they belong to the genus Mulinia. An important character of this genus is the absence of an externally visible ligament.

The genus Mulinia consists of ten recognized species (MolluscaBase 2018b). The shells of six Mulinia species have an oval outline (Signorelli and
Pastorino 2011; Coan and Valentich-Scott 2012; Signorelli and Pastorino 2012a; Signorelli and Pastorino 2012b). Four species have shells with a more triangular outline, the anterior and posterior margins being more angular and less rounded, viz. $M$. pontchartrainensis Morrison 1965, M. cleryana (d'Orbigny, 1846), M. pallida (Broderip \& G. B. Sowerby I, 1829) and M. lateralis (Say, 1822). The shells of $M$. pontchartrainensis, $M$. cleryana and $M$. pallida have a higher shape than those of $M$. lateralis, with the anterior and posterior end below the middle of the shell height (Morrison 1965; Signorelli and Pastorino 2012b).

Our specimens agree with the following combination of characteristics of Mulinia lateralis (Fig. 2), namely (1) triangular shell outline, (2) distinct radial ridge along posterior end of valves, (3) ligament exclusively internal, (4) accessory lamella well developed, (5) anterior lateral teeth in right valve of different sizes, the ventral one longer; two posterior lateral teeth similar in size, (6) shell colour whitish to cream, with thin, yellowish periostracum, may be thickened along the postero-dorsal margin past the 

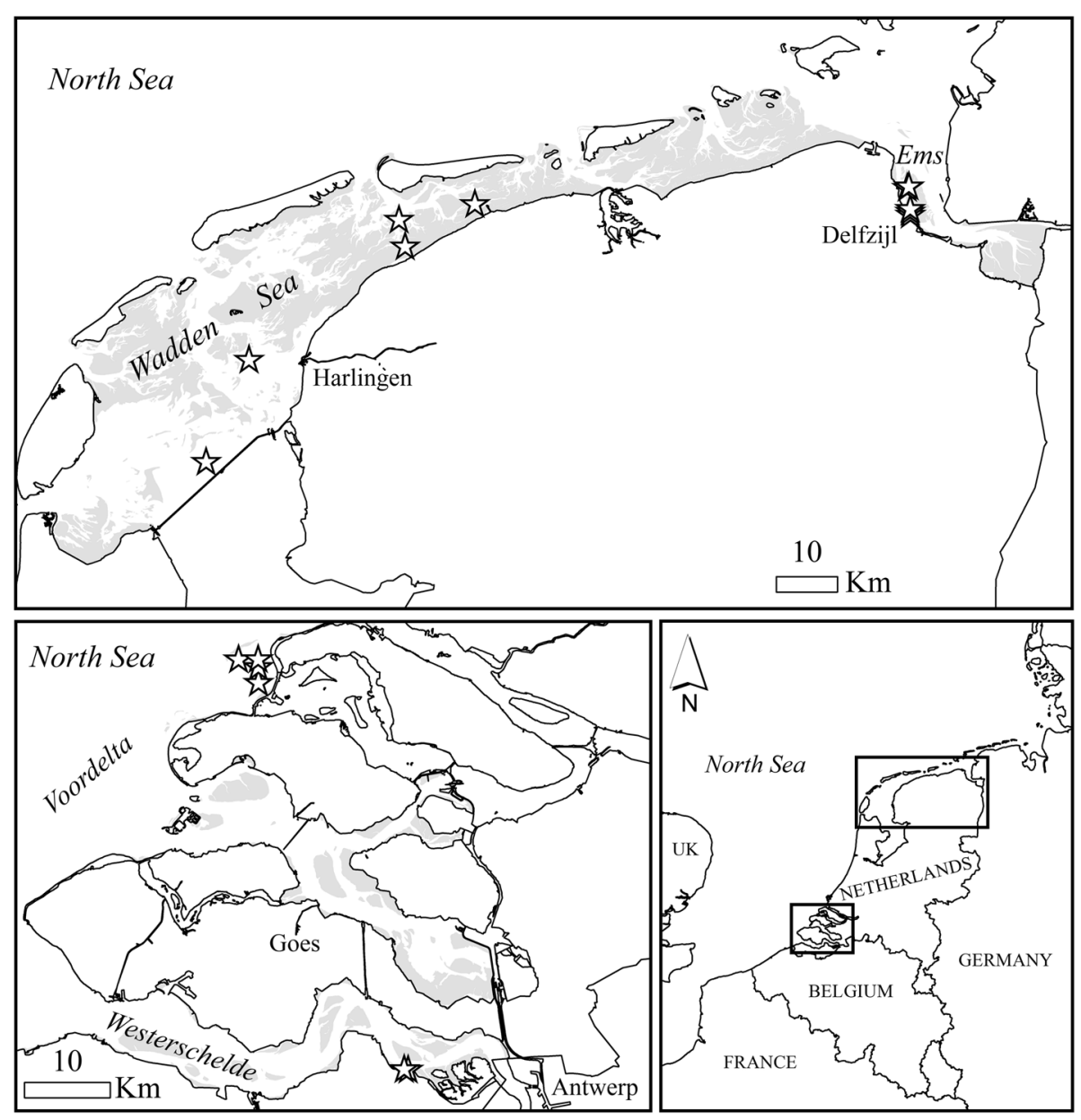

Fig. 1 Map of the Netherlands, with locations where Mulinia lateralis has been found

posterior ridge, (7) shell surface smooth with very fine concentric growth lines, (8) shell distinctly convex, (9) cardinal area between beaks broad in large specimens.

Literature sources differ considerably with respect to maximum length given for $M$. lateralis. (Abbott 1974) mentions $12.7 \mathrm{~mm}$ (0.5 in.), while the largest length class in a study by (Montagna et al. 1993) was $21 \mathrm{~mm}$. In the Voordelta we found animals between 7.2 and $17.8 \mathrm{~mm}$. Maximum length in the Wadden Sea was $21.2 \mathrm{~mm}$. The specimens in the Westerschelde were smaller, up to $7 \mathrm{~mm}$.

Main diagnostic characters of Mulinia lateralis for field identification are its whitish to cream colour, the presence of a radial ridge along the posterior end of the valves, and the distinctly convex shells. In the southern North Sea Mulinia lateralis is most likely to be confused with juvenile Mactra stultorum or juvenile Spisula subtruncata. Therefore, we list main morphological differences with those two species (Table 2) and provide illustrations of all three (Figs. 2, 3 and 4). Furthermore, we provide illustrations of another invasive species of Mactridae, namely Rangia cuneata (Fig. 5). Drawings were made with the aid of a drawing mirror on a Wild M5 stereomicroscope, based on following material: 1 specimen of Mulinia lateralis (length $21.2 \mathrm{~mm}$ ) collected in July 2018 from the Wadden Sea, 1 specimen of Mactra stultorum (length $21.9 \mathrm{~mm}$ ) and 1 specimen of Spisula subtruncata (length $21.2 \mathrm{~mm}$ ) collected from the Dutch coastal zone, 1 specimen of Rangia cuneata collected on 16 April 2018 from the Galgenweel in Antwerp (length $45.8 \mathrm{~mm}$ ). Specimens of $M$. stultorum and S. subtruncata similar in size to the specimen of $M$. lateralis were chosen for drawing in order to rule out morphological differences related to size. Similar-sized Rangia cuneata were not available to us. 
Table 2 Main morphological differences between Mulinia lateralis, Mactra stultorum and Spisula subtruncata

\begin{tabular}{|c|c|c|c|}
\hline & Mulinia lateralis & Mactra stultorum & Spisula subtruncata \\
\hline Shell outline & triangular & oval & triangular \\
\hline $\begin{array}{l}\text { Radial ridge along posterior } \\
\text { end of valves }\end{array}$ & distinct & absent & absent \\
\hline Ligament & exclusively internal & external ligament present & external ligament present \\
\hline $\begin{array}{l}\text { Accessory lamella (between } \\
\text { chondrophore and two } \\
\text { fused cardinal teeth) }\end{array}$ & well developed & very weak & very weak \\
\hline Shell colour & $\begin{array}{l}\text { whitish to cream with thin, } \\
\text { yellowish periostracum }\end{array}$ & $\begin{array}{l}\text { creamy white with purple hue around } \\
\text { umbos and brown radiating rays }\end{array}$ & dirty white with brown periostracum \\
\hline Shell surface & $\begin{array}{l}\text { smooth with very fine concentric } \\
\text { growth lines }\end{array}$ & smooth & $\begin{array}{l}\text { distinct concentric grooves along } \\
\text { dorsal line on either side of umbos }\end{array}$ \\
\hline Shell convexity & distinctly convex & valves moderately convex & $\begin{array}{l}\text { variable, with distinctly convex and } \\
\text { less convex forms (van Urk 1959) }\end{array}$ \\
\hline Cardinal area between beaks & broad in large specimens & narrow in large specimens & narrow in large specimens \\
\hline
\end{tabular}

To facilitate identification we provide below a key of all species of the subfamily Mactrinae of the NE Atlantic Ocean and adjacent brackish waters, partly after Tebble (1966).

- ligament exclusively internal 2

2. - external ligament separated from internal ligament by a calcareous septum; lateral teeth smooth

- external and internal ligaments not separated 4 (Spisula) by a calcareous septum; upper and lower surfaces of lateral teeth in left valve and inner surfaces of lateral teeth in right valve serrated

3. - anterior cardinal tooth of right valve almost parallel with hinge line; adults normally less than $6.35 \mathrm{~cm}$ long

- anterior cardinal tooth of right valve not parallel with hinge line; adults normally more than $6.35 \mathrm{~cm}$ long

4. - pallial sinus shallow, reaching to a point below and behind the middle of the posterior lateral tooth/teeth

6

3 (Mactra)

Mactra stultorum

(Fig. 3)

Mactra glauca

Spisula

subtruncata

(Fig. 4)

- pallial sinus deep, reaching to a point below 5 and in front of the middle of the posterior lateral tooth/teeth

5. - cardinal teeth of left valve reach more than halfway down the hinge plate; dorsal areas about the beaks with fine concentric lines

- cardinal teeth of left valve reach no more than halfway down the hinge plate; dorsal areas about the beaks with fine concentric grooves

6. - left valve with lamellar lateral teeth, posterior one short (length about one third of posterodorsal margin); upper and lower surfaces of these teeth smooth or with tiny crenulations, sometimes in indistinct rows; umbo on midline of shell and directed slightly forward at most

- left valve with stout lateral teeth, anterior one Lshaped, posterior one long (almost along entire postero-dorsal margin); upper and lower surfaces of these teeth serrated; umbo in front of midline of shell and directed markedly forward

\section{DNA based identification}

DNA was analyzed from 3 specimens collected in September 2018 in the Westerschelde. Soft tissue was removed from the shell, and conserved in 96\% Ethanol as soon as possible after collection. DNA was isolated from this tissue using the DNeasy Blood and Tissue kit (Qiagen) as per manufacturers protocol. 0,5 $\mu$ l of the isolated DNA was used as a template in a 25ul PCR reaction to amplify the $16 \mathrm{~S}$ gene of the mitochondrial DNA (primers 16S-F-ONT and 16S-R-ONT, containing an extension to allow for the addition of Oxford Nanopore Barcodes in a subsequent PCR step (Pomerantz et al. 2018); Phire Tissue Direct PCR master mix (Thermo Fisher). The amplification program was as follows: Initial denaturation, $3 \mathrm{~min}$ at $98^{\circ} \mathrm{C}, 30$ amplification cycles of $98^{\circ} \mathrm{C}, 8 \mathrm{~s} ; 61^{\circ} \mathrm{C}, 8 \mathrm{~s} ; 72^{\circ} \mathrm{C}, 20 \mathrm{~s}$; and $2 \mathrm{~min}$ final extension at $72{ }^{\circ} \mathrm{C} .4 \mu \mathrm{l}$ of this PCR mixture was directly used in a second 20ul barcoding PCR using the PCR barcoding expansion kit EXP-PBC096 (Oxford Nanopore) according to the manufacturers protocol, and again using Phire tissue direct PCR master mix. Barcoded PCR products were purified using the QIAquick PCR Purification Kit (Qiagen), and DNA was eluted in $15 \mu \mathrm{EB}$. DNA concentrations and purity were checked using Nanodrop (Thermo Fisher) and Qubit dsDNA HS DNA Assay kit (Thermo Fisher). Samples were pooled in equimolar ratios with several other samples and a sequencing library was prepared using the SQK-LSK108 sequencing kit (Oxford Nanopore) according to the manufacturers protocol. The DNA library was sequenced on a R9.4.1 flowcell in the MinION MK1b sequencer using MinKNOW 2.2.1 for $1 \mathrm{~h}$, with live base calling enabled. Obtained sequences were filtered on read length and quality using NanoFilt (De Coster et al. 2018) with settings to retain only reads between 500 and 800 nucleotides and a minimum q score of 9 . Filtered reads were 


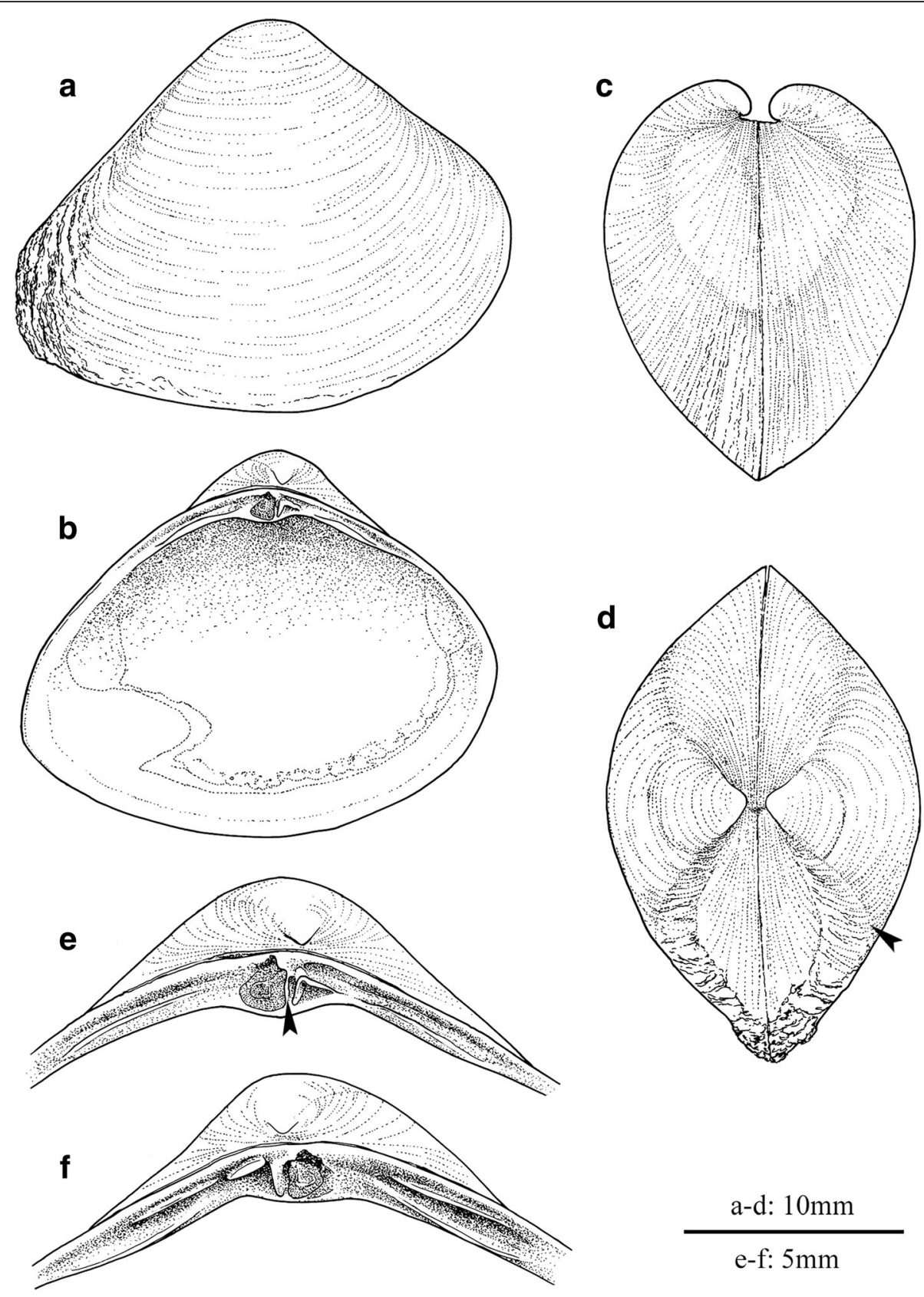

Fig. 2 Mulinia lateralis. a outside view of right valve; $\mathbf{b}$ inside view of left valve; $\mathbf{c}$ view of anterior regions of the two valves; $\mathbf{d}$ view of dorsal regions of the two valves (radial ridge arrowed); e hinge and umbonal region of left valve (accessory lamella arrowed); $\mathbf{f}$ hinge and umbonal region of right valve

trimmed of their sequencing adapters and barcodes and demultiplexed using Porechop (Wick et al. 2017). Approximately 50.000 reads were obtained for each of the three specimens. The first 100 reads were used to build a de novo consensus sequence using Canu V1.7 (Koren et al. 2017) with settings only correct reads, and optimized for short amplicons (canu -correct; genomeSize $=1000$, minReadLength $=400$ minOverlapLength $=300$ ). From the corrected reads the top one was used as a reference to further polish the sequence. First, 500 reads from the obtained amplicons were aligned to the reference using minimap2 (Li 2018) and this alignment was used as input for further polishing with Racon (Vaser et al. 2017).

The obtained consensus sequences had a length of 519, 516 and $511 \mathrm{bp}$. Blast was used to search for homology in NCBI nt database. The obtained consensus sequences were all $99 \%$ homologous to the $M$. lateralis references, despite some remaining homopolymer errors 


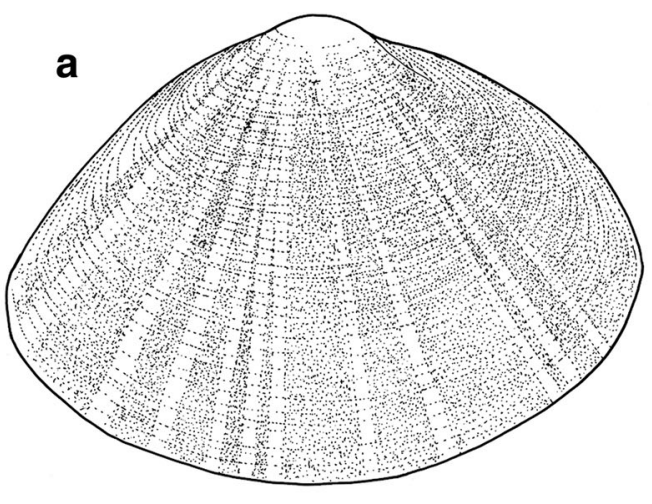

C
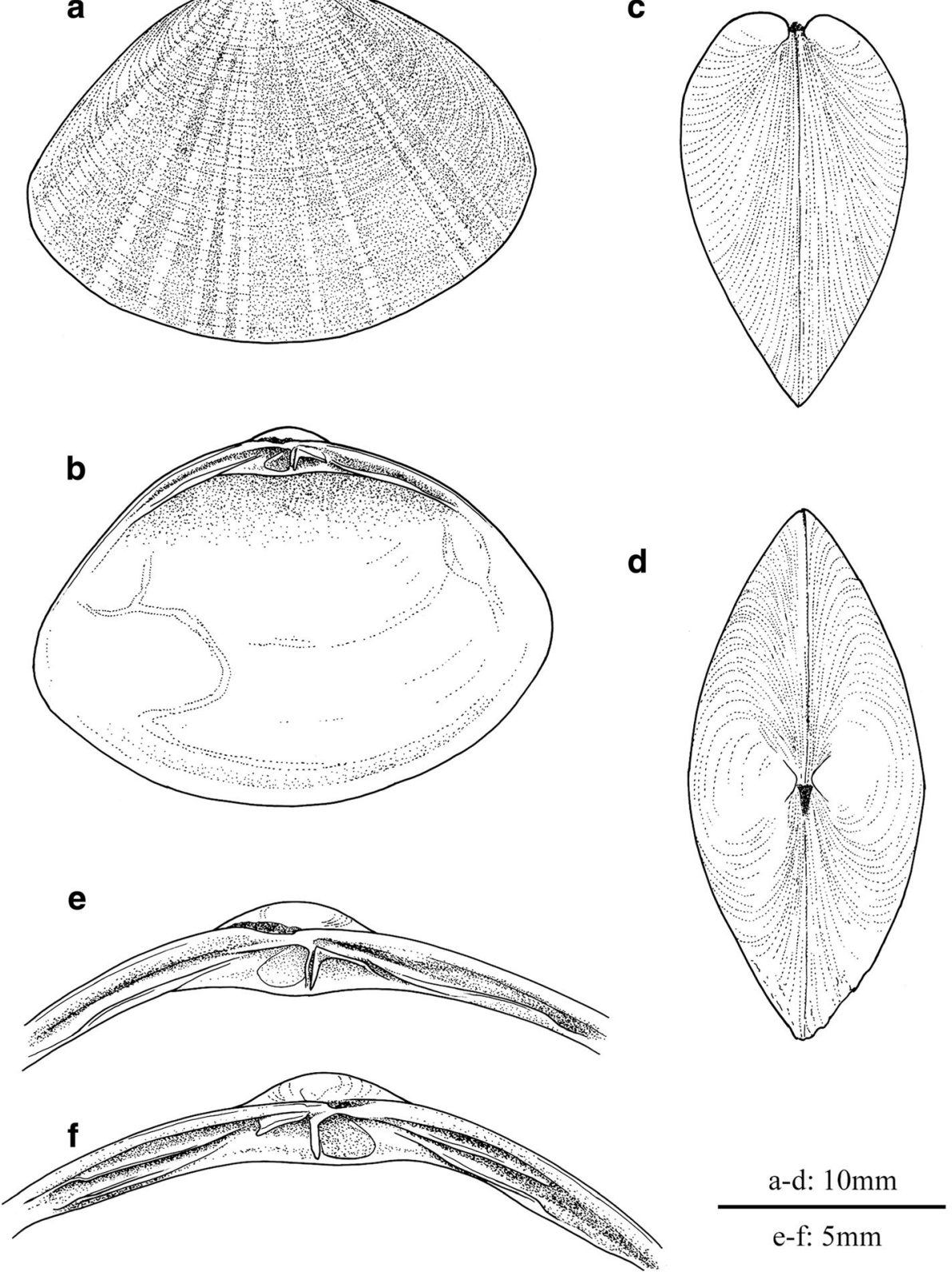

Fig. 3 Mactra stultorum. a outside view of right valve; $\mathbf{b}$ inside view of left valve; c view of anterior regions of the two valves; $\mathbf{d}$ view of dorsal regions of the two valves; $\mathbf{e}$ hinge and umbonal region of left valve; $\mathbf{f}$ hinge and umbonal region of right valve

in the nanopore consensus. The best hits in NCBI nt not being M. lateralis were Rangia cuneata (sequence homology of $88 \%$ ) and Spisula solida (homology of $84 \%)$. Sequences obtained from the three specimens were manually corrected for the homopolymer errors based on an alignment with $M$. lateralis reference sequences KT959479 and KX713236, and the resulting sequences are deposited at Genbank, accession numbers: MK026966-MK026968.

\section{Discussion}

The native distribution of Mulinia lateralis is the western Atlantic Ocean, ranging from the Gulf of St Lawrence to the Gulf of Mexico (Brunel et al. 1998; Turgeon et al. 2009). It is widely reported from bays along the Atlantic and Gulf coasts of the U.S., in a large range of salinities, from 5 to 80 ppt (Parker, 1975 in Montagna et al. 1993). It appears, however, to be a mainly estuarine species (Walker and Tenore 1984; Montagna and Kalke 1995). In 


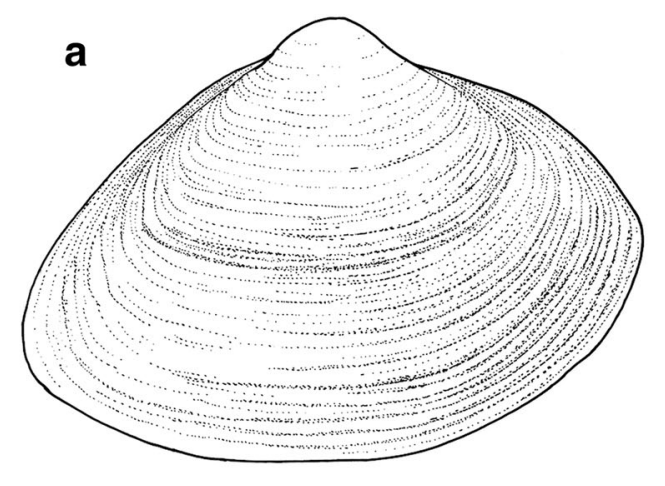

C
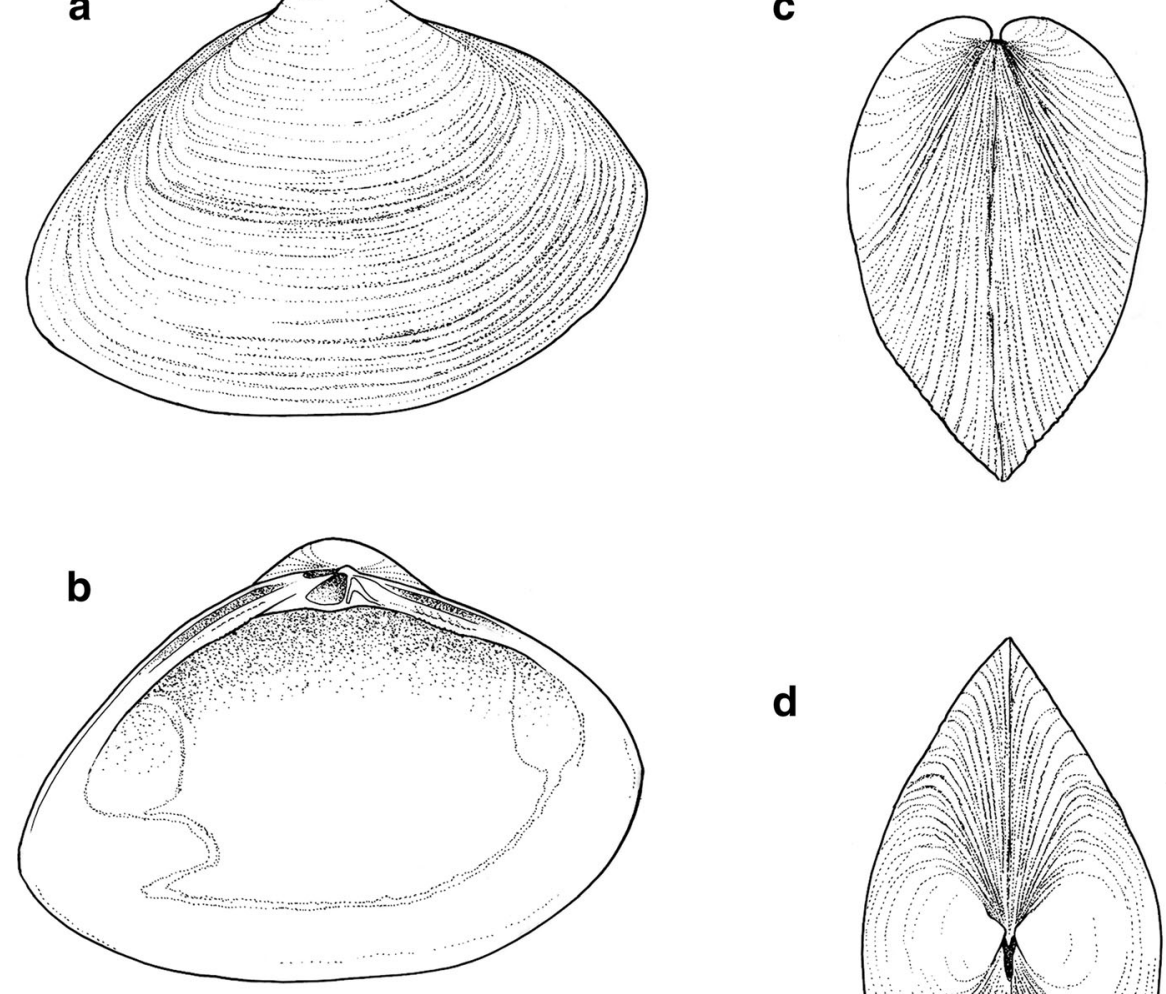

d
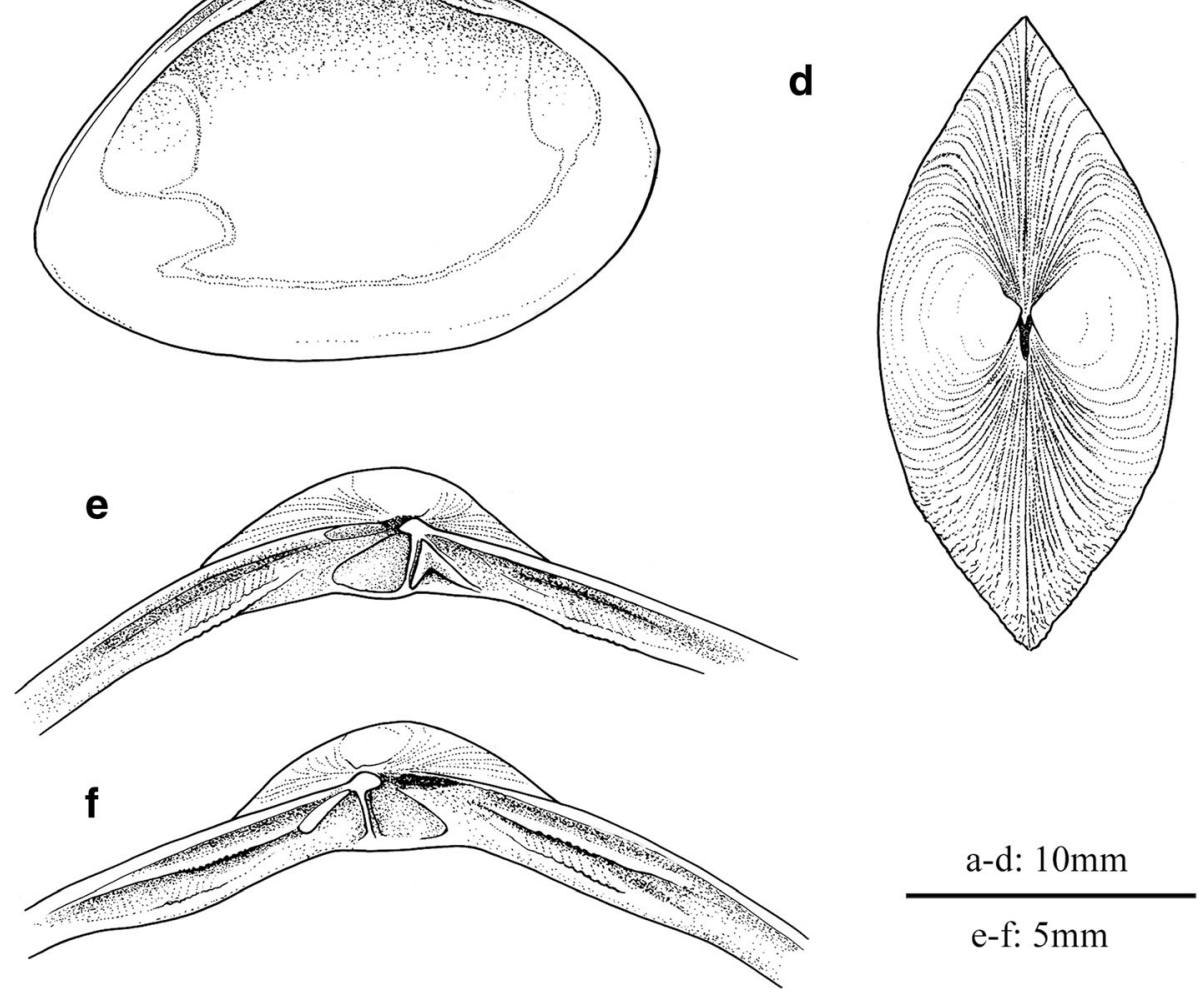

Fig. 4 Spisula subtruncata. a outside view of right valve; $\mathbf{b}$ inside view of left valve; c view of anterior regions of the two valves; $\mathbf{d}$ view of dorsal regions of the two valves; $\mathbf{e}$ hinge and umbonal region of left valve; $\mathbf{f}$ hinge and umbonal region of right valve

samples collected by Montagna and Kalke (1995) $M$. lateralis was dominant at four stations where there was freshwater influence, while at two other stations other bivalves were dominant. McKeon et al. (2015) report that $M$. lateralis composes a large portion of the total bivalve abundance at mixohaline sites (5-30 ppt) but quickly decreases in euhaline sites. They found $M$. lateralis has the most variable occurrence of all bivalve species they studied. They suggest that the tremendous variability seen in this species' occurrence could be a result of salinity 'windows of opportunity' for the larvae to colonize polyhaline sites. The Voordelta is mostly saline, but in periods of high freshwater discharges, salinity in some parts becomes less than $25 \mathrm{ppt}$ for several days, among others in the area where dwarf surf clams were found. Both the Westerschelde and the Wadden Sea can be characterized as estuarine environments. The eastern part of the Westerschelde, where $M$. lateralis was found, is brackish.

With respect to introduced species, most attention is being paid to species that become invasive, i.e. having 


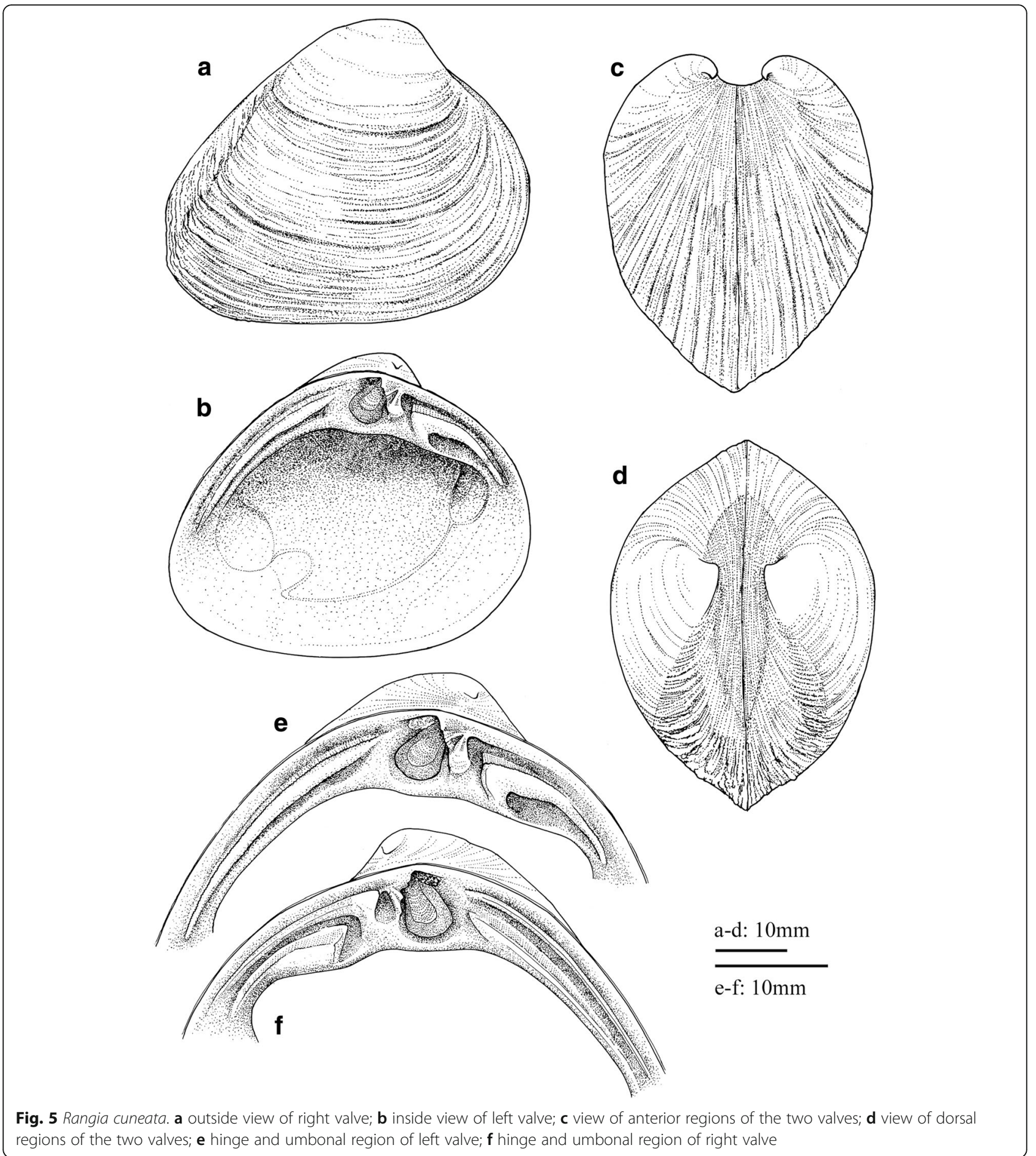

negative ecological and/or economic impact. Examples of invasive species in the North Sea coastal waters are the razor shell Ensis leei (Beukema and Dekker 1995; Tulp et al. 2010; Gollasch et al. 2015; Witbaard et al. 2015). the Pacific oyster Crassostrea gigas (Smaal et al. 2005; Nehls and Büttger 2007; Troost 2010) and the Asian shore crabs Hemigrapsus sanguineus and $H$. penicillatus (Noël et al. 1997; Gollasch 1999; Jungblut et al. 2017). Will Mulinia lateralis become the next invasive species? Although no generalizations should be made about links between species' attributes and its invasive ability (Manchester and Bullock 2000), its native range and ecology in that area might give some first indications. 
Mulinia lateralis is a typical r-selected species (Williams et al. 1986). It has a very short generation time, individuals being able to spawn at a length of $3 \mathrm{~mm}$ and at an age of 60 days, and probably more than once a year (Calabrese 1970). It has a short life span, up to 2 years, and a high fecundity (Lu et al. 1996). The species has a pelagic planktotrophic larval stage that lives in the plankton from 7 to 22 days (Mann et al. 1991) and, thus, a generation time of about 3 months (Guo and Allen 1994). In some areas, however, a continuous period of settling from a single spawning cycle has been reported, as well as year-round spawning (Montagna et al. 1993). It is a rapid colonizer after different types of disturbance. It has been found to be one of the numerically dominant species in Tampa Bay after summer defaunations (Santos and Simon 1980), likely because it is well-adapted to short-term anoxia (Shumway et al. 1983). McKeon et al. (2015) observed that $M$. lateralis was most abundant at sites with 'poor water quality', and has a tolerance for "muck" at poor water quality sites.

In conclusion, $M$. lateralis seems to have many characteristics to become a successful invader, as was the case for E. leei in the NE Atlantic (Dannheim and Rumohr 2012; Gollasch et al. 2015): planktonic larvae, short generation time, rapid growth. However, success will also depend on, among others, predation, available habitats and competition with native shellfish. At the moment $M$. lateralis is only known from a restricted area in the Northeast Atlantic. However, some species may be present for many years before they exhibit invasive characteristics (Aikio et al. 2010; Piria et al. 2017).

In its native range, $M$. lateralis is a desirable prey for crabs and fish (Calabrese 1970; Montagna et al. 1993). Even large Mulinia live very close to the sediment surface and are thus easily available to predators. Predation by crabs and fish is probably the major factor controlling adult population size, at least during warmer months (Virnstein 1977, 1979). We expect this to be the same in European waters, as has been documented for native species (Sanchez-Salazar et al. 1987; Hiddink et al. 2002; Andresen and van der Meer 2010). It is also an important food item for starfish (Mcclintock and Lawrence 1985), ducks (Cronan 1957; Montagna and Kalke 1995; Berlin 2018) and shorebirds (Britton and Morton 1989; Smith et al. 2016). Thus, in North Sea coastal waters, the species might be a new and/or alternative prey for shorebirds (such as oystercatcher, sanderling and red knot) and sea-ducks (such as common scoter, common eider, greater scaup).

Introductions can also have marked effects on populations of native species and biodiversity, and modify native habitats (Manchester and Bullock 2000; Bax et al. 2003). The most obvious is by modifying the habitat, or through increasing predation on native organisms.
Intra-guild predation of Hemigrapsus sanguineus upon Carcinus maenas may be one of the reasons $H$. sanguineus outnumbered $C$. maenas at some places, besides enhanced larval settling rates and competition for space (i.e. sheltered areas) (Jungblut et al. 2017). Filter feeding non-native bivalves may compete for space and food with native bivalves, especially if the non-native species can easily spread into all available habitats at high population densities. In the Venice lagoon, for instance, the non-native Manila clam, Ruditapes philippinarum, is now the dominant bivalve species, and native species such as Ruditapes decussatus are now rare (Pranovi et al. 2006). This also seems to be a realistic scene for the opportunistic Mulinia lateralis. Most bivalve species largely utilize the same food source and are therefore competitors for food. Whether food competition leads to an introduced species out-competing indigenous species is dependent on many factors such as filtration capacity, selection and absorption efficiency, and energy demand (Shumway and Newell 1984; Troost 2010). M. lateralis is adapted to quickly exploit the high concentrations of phytoplankton and natural seston which occur at the sediment-water interface but has a relatively high energy demand and an apparent inability to catabolize protein during prolonged periods of starvation which may be the cause of observed mass mortalities (Shumway and Newell 1984). M. lateralis may therefore be a weak competitor for food. In the Voordelta M. lateralis was found together with Spisula subtrucata. At the same station the highest density of both $M$. lateralis $\left(5872 \mathrm{ind} / \mathrm{m}^{2}\right)$ and of $S$. subtruncata (955 ind $/ \mathrm{m}^{2}$ ) was found. In the Westerschelde $M$. lateralis $\left(820 \mathrm{ind} / \mathrm{m}^{2}\right.$ ) was found together with high densities of small Cerastoderma edule (1756 ind $\left./ \mathrm{m}^{2}\right)$. Apparently, as M. lateralis seems to settle in high densities together with other bivalves, it will compete both for space and food with native bivalves.

\section{Conclusion}

Mulinia lateralis has established populations in estuarine areas and coastal waters of the Netherlands. In view of its ecology and distributional range in the native area it has the potential to become an invasive species. For the same reasons dispersal to other areas in Europe is likely.

\footnotetext{
Acknowledgements

We thank all colleagues at Wageningen Marine Research, eCOAST and Eurofins, and inspectors of the Waddenunit of the Ministry of Nature, Agriculture and Food Quality, who were involved in the data collection. The Spring data in the Wadden Sea, Eems and Voordelta were collected within the framework of the statutory annual shellfish stock assessments (commissioned by the Dutch Ministry of Nature, Agriculture and Food Quality and the Dutch Producers' Organization Mussel culture, and carried out annually by Wageningen Marine Research and Bureau MarinX).

Autumn data along the south-west coast of the Voordelta were collected within the framework of a monitoring program aimed at evaluating the ecological effects of measures taken to compensate for the extension of the
} 
harbour of Rotterdam. The program is financed by Rijkswaterstaat - Water, Verkeer en Leefomgeving.

Data in the Westerschelde were provided by Dr. B. Walles (Wageningen Marine Research). They were obtained from a program monitoring restoration of estuarine habitats in the Westerschelde estuary, financed by the Province of Zeeland.

\section{Funding}

Data were collected in framework of different monitoring programs. See acknowledgments.

\section{Availability of data and materials}

The datasets generated during and/or analysed during the current study are available from the corresponding author on reasonable request. At a later stage the data will become publicly available, through the Dutch Marine Information and Data Centre (IHM) (https://www.informatiehuismarien.nl/uk).

\section{Authors' contributions}

$J \mathrm{C}$ and $\mathrm{KT}$ are project leaders of the main monitoring programs. MF and $\mathrm{HG}$ made the identification key. KT made Fig. 1, HG made the Figs. 2, 3, 4 and 5. $M F, H G, A E, K P, D v d E$ and JvZ were involved in the field work, found the new species and contributed to the final identification. RN did the DNA based identifications, and wrote the parts of the ms about these analyses. All authors were involved in the setup of the manuscript, lead by JC. All authors read and approved the final manuscript.

\section{Ethics approval and consent to participate}

Not applicable.

\section{Consent for publication}

Not applicable.

\section{Competing interests}

The authors declare that they have no competing interests.

\section{Publisher's Note}

Springer Nature remains neutral with regard to jurisdictional claims in published maps and institutional affiliations.

\section{Author details}

'Wageningen Marine Research, Wageningen University, P.O. Box 77, 4400, $A B$, Yerseke, the Netherlands. ${ }^{2}$ CCOAST Marine Research, Korringaweg 7 , 4401, NT, Yerseke, the Netherlands. ${ }^{3}$ Naturalis Biodiversity Center, Pesthuislaan 7, 2333, BA, Leiden, the Netherlands. ${ }^{4}$ Eurofins AquaSense, H.J.E. Wenckebachweg 120, 1114, AD, Amsterdam-Duivendrecht, the Netherlands. ${ }^{5}$ Marine Animal Ecology Group, Wageningen University, P.O. Box 338, 6700, AH, Wageningen, The Netherlands.

\section{Received: 25 October 2018 Accepted: 14 February 2019}

\section{Published online: 05 March 2019}

\section{References}

Abbott R. American seashells; the marine molluska of the Atlantic and Pacific coasts of North America. New York: Van Nostrand Reinhold; 1974.

Aikio S, Duncan RP, Hulme PE. Lag-phases in alien plant invasions: separating the facts from the artefacts. Oikos. 2010;119:370-8.

Andresen $\mathrm{H}$, van der Meer J. Brown shrimp (Crangon crangon, L.) functional response to density of different sized juvenile bivalves Macoma balthica (L.). J Exp Mar Biol Ecol. 2010;390:31-8.

Australia. Invasive Plants and Animals Committee, Australian Pest Animal Strategy 2017 to 2027. Canberra: Australian Government Department of Agriculture and Water Resources; 2016.

Bax N, Williamson A, Aguero M, Gonzalez G, Geeves W. Marine invasive alien species: a threat to global biodiversity. Mar Policy. 2003;27:313-23.

Berlin A. Foraging values of Mulinia lateralis and Ischadium recurvum: energetics effects of surf scoters wintering in the Chesapeake Bay. PhD Thesis. Baltimore: University of Maryland; 2018.

Beukema JJ, Dekker R. Dynamics and growth of a recent invader into European coastal waters: the Amerikan razor clam, Ensis directus. J Mar Biol Assoc U K. 1995;75:351-62.
Britton J, Morton B. Shore ecology of the Gulf of Mexico. Austin: University of Texas Press; 1989.

Brunel P, Bossé L, Lamarche G. Catalogue of the Marine Invertebrates of the Estuary and Gulf of Saint Lawrence, Canadian Special Publication of Fisheries \& Aquatic Sciences No. 126. Ottawa: Department of Fisheries and Oceans; 1998.

Calabrese A. Reproductive cycle of the coot clam, Mulinia lateralis (Say), in Long Island sound. Veliger. 1970;12:265-9.

Canada. Aquatic invasive species regulations. Canada Gazette. 2014;148:1-61.

Coan EV, Valentich-Scott P. Bivalve seashells of tropical West America : marine bivalve mollusks from Baja California to northern Perú. Santa Barbara: Santa Barbara Museum of Natural History; 2012.

Cronan J. Food and feeding habits of the scaups in Connecticut waters. Auk. 1957;74:459-68.

Dannheim J, Rumohr H. The fate of an immigrant: Ensis directus in the eastern German bight. Helgoland Mar Res. 2012;66:307-17.

De Coster W, D'Hert S, Schultz DT, Cruts M, Van Broeckhoven C. NanoPack: visualizing and processing long-read sequencing data. Bioinformatics. 2018; 34:2666-9.

Elton C. The ecology of invasions by plants and animals. London: Chapman and Hall; 1958.

EU. Regulation (EU) No 1143/2014 of the European Parliament and of the Counci of 22 October 2014 on the prevention and management of the introduction and spread of invasive alien species. Off J Eur Union. 2014;L 317/35: 35-55. Strasbourg: European Union.

Faasse M. Haminoaea japonica Pilsbry, 1895 (Gastropoda: Cephalaspidea) new to the Netherlands. Spirula. 2018a;416:16-9.

Faasse M. A record of the Asian mussel Arcuatula senhousia (Benson in cantor, 1842) from NW Europe (the Netherlands). Spirula. 2018b;416:14-5.

Gardner J. The molluscan fauna of the Alum Bluff group of Florida. Part V. Tellinacea, Solenacea, Mactracea, Myacea, Molluscoidea, Professional Paper 142 E. Washington: U.S. Geological Survey; 1928. p. 185-249.

Gollasch S. The Asian decapod Hemigrapsus penicillatus (de Haan, 1835) (Grapsidae, Decapoda) introduced in European waters: status quo and future perspective. Helgolander Meeresun. 1999;52:359-66.

Gollasch S, Haydar D, Minchin D, Reise K, Wolff W. Biological invasions in marine ecosystems: ecological, management, and geographic perspectives. In: Rilov G, Crooks JA, editors. Biological invasions in marine ecosystems: ecological, management, and geographic perspectives. Berlin: Springer; 2008. p. 507-28.

Gollasch S, Kerckhof F, Craeymeersch J, Goulletquer P, Jensen K, Jelmert A, Minchin D. Alien species alert: Ensis directus. Current status of invasions by the marine bivalve Ensis directus, ICES cooperative research report. Copenhagen: ICES; 2015.

Guo XM, Allen SK. Sex determination and Polyploid gigantism in the dwarf Surfclam (Mulinia lateralis say). Genetics. 1994;138:1199-206.

Hiddink JG, Marijnissen SAE, Troost K, Wolff WJ. Predation on O-group and older year classes of the bivalve Macoma balthica: interaction of size selection and intertidal distribution of epibenthic predators. J Exp Mar Biol Ecol. 2002;269: 223-48.

Jungblut S, Beermann J, Boos K, Saborowski R, Hagen W. Population development of the invasive crab Hemigrapsus sanguineus (De Haan, 1853) and its potential native competitor Carcinus maenas (Linnaeus, 1758) at Helgoland (North Sea) between 2009 and 2014. Aquat Invasions. 2017;12:85-96.

Koren S, Walenz BP, Berlin K, Miller JR, Bergman NH, Phillippy AM. Canu: scalable and accurate long-read assembly via adaptive $k$-mer weighting and repeat separation. Genome Res. 2017;27:722-36.

Li H. Minimap2: pairwise alignment for nucleotide sequences. Bioinformatics. 2018;34:3094-100.

Lu JK, Chen TT, Allen SK, Matsubara T, Burns JC. Production of transgenic dwarf surfclams, Mulinia lateralis, with pantropic retroviral vectors. P Natl Acad Sci USA. 1996;93:3482-6.

Manchester SJ, Bullock JM. The impacts of non-native species on UK biodiversity and the effectiveness of control. J Appl Ecol. 2000;37:845-64.

Mann R, Campos BM, Luckenbach MW. Swimming rate and responses of larvae of 3 Mactrid bivalves to salinity discontinuities. Mar Ecol Prog Ser. 1991;68: 257-69.

Marbuah G, Gren I-M, McKie B. Economics of harmful invasive species: a review. Diversity. 2014;6:500-23.

Mcclintock JB, Lawrence JM. Characteristics of foraging in the soft-bottom benthic starfish Luidia-Clathrata (Echinodermata, Asteroidea) - prey selectivity, switching behavior, functional-responses and movement patterns. Oecologia. 1985;66:291-8. 
McKeon CS, Tunberg BG, Johnston CA, Barshis DJ. Ecological drivers and habitat associations of estuarine bivalves. Peerj. 2015;3:e1348.

MolluscaBase. Mactridae Lamarck, 1809. 2018a. Accessed through: World Register of Marine Species at: http://www.marinespecies.org/aphia.php?p= taxdetails\&id=230. Accessed 09-01-2018.

MolluscaBase. Mulinia Gray, 1837. 2018b. Accessed through: World Register of Marine Species at: http://marinespecies.org/aphia.php?p=taxdetails\&id= 156869. Accessed 30 Aug 2018.

Montagna PA, Kalke R. Ecology of infaunal Mollusca in South Texas estuaries. Am Malacol Bull. 1995;11:163-75.

Montagna PA, Stockwell DA, Kalke RD. Dwarf Surfclam Mulinia lateralis (say, 1822) populations and feeding during the Texas Brown tide event. J Shellfish Res. 1993;12:433-42

Morrison JPE. New brackish water mollusks from Louisiana proc. Biol Soc Wash. 1965;78:217-24

Nehls G, Büttger H. Spread of the Pacif Oyster Crassostrea gigas in the Wadden Sea. Causes and consequences of a successful invasion, HARBASINS Report: 2007. p. 54

Noël PY, Tardy E, D'Udekem C. Will the crab Hemigrapsus penicillatus invade the coasts of Europe? C R Acad Sc Paris. 1997;320:741-5.

Parker RH. The study of benthic communities: a model and a review. New York: Elsevier; 1975

Piria M, Copp G, Dick J, Dupli A, Groom Q, Jeli D, Lucy F, Roy HE, Sarat E, Simonovi $\mathrm{P}$, Tomljanovi T, Tricarico E, Weinlander M, Adámek Z, Bedolfe S, Coughlan N, Davis E, Dobrzycka-Krahel A, Grgi Z, Kirankaya \$̧, Ekmekçi F, Lajtner J, Lukas J, Koutsikos N, Mennen G, Miti B, Pastorino P, Ruokonen T, Skóra M, Smith E, Šprem N, Tarkan A, Treer T, Vardakas L, Vehanen T, Vilizzi L, Zanella $\mathrm{E}$, Caffre J. Tackling invasive alien species in Europe II: threats and opportunities until 2020. Manag Biol Invasion. 2017:8:273-86.

Pomerantz A, Peñafiel N, Arteaga A, Bustamante L, Pichardo F, Coloma LA, BarrioAmorós CL, Salazar-Valenzuela D, Prost S. Real-time DNA barcoding in a rainforest using nanopore sequencing: opportunities for rapid biodiversity assessments and local capacity building. GigaScience. 2018;7. https://doi.org/ 10.1093/gigascience/giy033.

Pranovi F, Franceschini G, Casale M, Zucchetta M, Torricelli P, Giovanardi O. An ecological imbalance induced by a non-native species: the Manila clam in the Venice lagoon. Biol Invasions. 2006;8:595-609.

Reise K, Gollasch S, Wolff WJ. Introduced marine species of the North Sea coasts. Helgolander Meeresun. 1999;52:219-34.

Rilov G, Crooks JA. Biological invasions in marine ecosystems : ecological, management, and geographic perspectives. Berlin: Springer; 2009.

Sanchez-Salazar ME, Griffiths CL, Seed R. The interactive roles of predation and tidal elevation in structuring populations of the edible cockle, Cerastoderma edule. Estuar Coast Shelf S. 1987;25:245-60.

Santos SL, Simon JL. Response of soft-bottom benthos to annual catastrophic disturbance in a South Florida estuary. Mar Ecol Prog Ser. 1980;3:347-55.

Shumway SE, Newell RC. Energy resource-allocation in Mulinia lateralis (say), an opportunistic bivalve from shallow-water sediments. Ophelia. 1984;23:101-18.

Shumway SE, Scott TM, Shick JM. The effects of anoxia and hydrogen-sulfide on survival, activity and metabolic-rate in the coot clam, Mulinia lateralis (say). J Exp Mar Biol Ecol. 1983;71:135-46.

Signorelli JH, Carter JG. The Anatinellidae and Kymatoxinae: a reassessment of their affinities within the superfamily Mactroidea (Mollusca, Bivalvia). Am Malacol Bull. 2016;33:204-11.

Signorelli JH, Pastorino G. Revision of the Magellanic Mactridae Lamarck, 1809 (Bivalvia: Heterodonta). Zootaxa. 2011;2757:47-67.

Signorelli $\mathrm{JH}$, Pastorino G. A revision of the living Mactridae (Bivalvia: Autobranchia) from northern Argentina and Uruguay. Am Malacol Bull. 2012a:30:85-101.

Signorelli JH, Pastorino G. Taxonomic revision of Brazilian Mactridae Lamarck, 1809 (Bivalvia: Cardiida). Zootaxa. 2012b;3245:30-53.

Smaal A, van Stralen M, Craeymeersch J. Does the introduction of the Pacific oyster Crassostrea gigas lead to species shifts in the Wadden Sea? In: Dame $\mathrm{RF}$, Olenin S, editors. The comparative roles of suspension-feeders in ecosystems. Dordrecht: Kluwer Academic Publishers; 2005. p. 277-89.

Smith F, Watts B, Lyons J, Keyes T. Investigating Population Dynamics of Red Knot Migration along the Georgia Coast through Mark/Recapture Analysis of Resights: 2015 Spring Season, Center for Conservation Biology Technical Report Series, CCBTR-16-05. Williamsburg: College of William and Mary/ Virginia Commonwealth University; 2016. p. 13.
Tebble N. British bivalve seashells: a handbook for identification. London: British Museum (Natural History); 1966.

Troost K. Causes and effects of a highly successful marine invasion: case-study of the introduced Pacific oyster Crassostrea gigas in continental NW European estuaries. J Sea Res. 2010;64:145-65.

Tulp I, Craeymeersch J, Leopold M, van Damme C, Fey F. The role of the invasive bivalve species Ensis directus as food source for fish and birds in the Dutch coastal zone. Estuar Coast Shelf Sci. 2010;90:116-28.

Turgeon DD, Lyons W, Mikkelsen P, Rosenberg G, Moretzsohn F. Bivalvia (Mollusca) of the Gulf of Mexico. In: Felder DL, Camp D, editors. Gulf of Mexico-Origins, Waters, and Biota. Biodiversity. Texas: Texas A\&M University Press; 2009. p. 711-44.

van Urk RM. De Spisula's van het Nederlandse strand. Basteria. 1959;23:1-32.

Vaser R, Sovic I, Nagarajan N, Sikic M. Fast and accurate de novo genome assembly from long uncorrected reads. Genome Res. 2017;27:737-47.

Virnstein RW. Importance of predation by crabs and fishes on benthic infauna in Chesapeake Bay. Ecology. 1977;58:1199-217.

Virnstein RW. Predation on estuarine in-Fauna - response patterns of component species. Estuaries. 1979;2:69-86.

Walker RL, Tenore KR. Growth and production of the dwarf surf clam Mulinia lateralis (say 1822) in a Georgia estuary. Gulf Res Rep. 1984;7:357-63.

WGITMO. Interim Report of the Working Group on Introductions and Transfers of Marine Organisms (WGITMO), ICES WGITMO REPORT 2018. Ices cm 2018/ HAPISG:11. Copenhagen: ICES; 2018. p. 181.

Wick RR, Judd LM, Gorrie CL, Holt KE. Completing bacterial genome assemblies with multiplex MinION sequencing. Microbial Genomics. 2017:3:e000132.

Williams JB, Copeland BJ, Monroe RJ. Population-dynamics of an R-selected bivalve, Mulinia lateralis (say) in a North-Carolina estuary. Contrib Mar Sci. 1986;29:73-89.

Witbaard R, Duineveld GCA, Bergman MJN, Witte HIJ, Groot L, Rozemeijer MJC. The growth and dynamics of Ensis directus in the near-shore Dutch coastal zone of the North Sea. J Sea Res. 2015;95:95-105.

Wolff WJ. Non-indigenous marine and estuarine species in the Netherlands. Zool Med Leiden. 2005;79:1-116.

Zettler ML, Beermann J, Dannheim J, Ebbe B, Grotjahn M, Günther C-P, Gusky M, Kind B, Kröncke I, Kuhlenkamp R, Orendt C, Rachor E, Schanz A, Schröder A, Schüler L, Witt J. An annotated checklist of macrozoobenthic species in German waters of the north and Baltic seas. Helgoland Mar Res. 2018;72:5.

\section{Ready to submit your research? Choose BMC and benefit from:}

- fast, convenient online submission

- thorough peer review by experienced researchers in your field

- rapid publication on acceptance

- support for research data, including large and complex data types

- gold Open Access which fosters wider collaboration and increased citations

- maximum visibility for your research: over $100 \mathrm{M}$ website views per year

At BMC, research is always in progress.

Learn more biomedcentral.com/submissions 